\title{
Analisis Miskonsepsi Siswa Kelas VII SMP Dengan Menggunakan Three Tier Test Pada Materi Aljabar
}

\author{
Zainal Abidin ${ }^{1)}$, Sitti Mania ${ }^{2)}$, Andi Kusumayanti ${ }^{3)}$ \\ ${ }^{1,2,3}$ Fakultas Tarbiyah dan Keguruan UIN Alauddin Makassar \\ $\underline{\text { 12abidin.zaenal@gmail.com }}{ }^{l)}$, sitti.mania@uin-alauddin.com ${ }^{2)}$, ${\text { andi.kusumayanti@uin-alauddin.ac.id }{ }^{3)}}$
}

\begin{abstract}
Abstrak
Penelitian ini bertujuan untuk mengetahui miskonsepsi yang dialami siswa kelas VII SMP Negeri 17 Makasssar pada materi bentuk dan operasi aljabar untuk mengetahui penyebab miskonsepsi siswa kelas VII 2 SMP Negeri 17 Makasssar pada materi bentuk dan operari aljabar. Permasalahan yang dikaji dalam penelitian ini adalah miskonsepsi materi aljabar yang dialami oleh siswa. Jenis penelitian ini adalah penelitian kualitatif. Subjek pada penelitian ini adalah siswa kelas VII 2 SMP Negeri 17 Makassar. Teknik pengumpulan data pada penelitian ini adalah tes diagnostik three tier test, wawancara dan dokumentasi. Teknik analisis data menggunakan 1) reduksi data, 2) display data, 3) kesimpulan dan verifikasi. Hasil penelitian menunjukkan bahwa 1) hasil three tier-test yang diberikan kepada siswa kelas VII 2, teridentifikasi siswa mengalami miskonsepsi pada materi aljabar dengan persentase 33\% dari 30 siswa. Miskonsepsi mayoritas terjadi pada semua materi aljabar yaitu konsep aljabar, unsur-unsur aljabar, operasi penjumlahan, operasi pengurangan, operasi perkalian dan operasi pembagian, 2) faktor-faktor penyebab miskonsepsi siswa kelas VII 2 SMP Negeri 17 Makassar adalah kurangnya kemampuan siswa dalam memahami konsep aljabar secara menyeluruh, kurangnya minat belajar siswa, dan metode yang digunakan oleh guru yaitu metode ceramah sehingga membuat siswa kesulitan memahami materi aljabar dan prakonsep praaljabar.
\end{abstract}

Kata Kunci: Miskonsepsi, Three Tier Test, Aljabar

\section{Pendahuluan}

Pendidikan mempunyai peranan yang sangat penting dalam membangun sumber daya manusia yang berkualitas. Selain itu, pendidikan juga mempunyai arti yang sangat penting dalam kehidupan. Oleh karena itu, pendidikan harus dilakukan sebaik-baiknya sehingga memperoleh hasil yang optimal. Pendidikan sering diartikan sebagai usaha manusia membina kepribadiannya sesuai dengan nilai-nilai di masyarakat dan kebudayaan dalam perkembangannya. Istilah pendidikan berarti bimbingan atau pertolongan yang diberikan dengan sengaja oleh orang dewasa agar ia menjadi dewasa. Selanjutnya, pendidikan diartikan sebagai usaha yang dijalankan oleh seseorang atau kelompok orang lain agar menjadi dewasa atau mencapai tingkat hidup atau penghidupan yang lebih tinggi dalam arti mental. Manusia memiliki banyak potensi yang ada dalam dirinya (Hasbullah, 2013).

Di masa sekarang ini, matematika masih menjadi masalah sebagian besar siswa. Sebagian besar siswa menganggap bahwa matematika merupakan pelajaran yang sulit karena berisi tentang perhitungan angka-angka yang rumit dan kumpulan aturan-aturan yang perlu dipahami. Salah satu materi yang dianggap susah dalam pembelajaran matematika khususnya siswa SMP adalah aljabar. Ketika siswa belajar tentang aljabar mereka masih sering mengalami kesalahan konsep dalam memahaminya. Ada banyak hal yang harus dikuasai siswa dalam memahami konsep aljabar meliputi bentuk aljabar dan unsur-unsurnya, persamaan dan pertidaksamaan linear serta penyelesaiannya, himpunan dan operasinya, relasi, fungsi dan grafiknya. Konsep aljabar tersebut dapat diberikan dan ditanamkan secara efektif dengan mengajarkan aljabar di sekolah. Melalui matematika, aljabar mulai diperkenalkan kepada siswa di tingkat Sekolah Menengah Pertama (SMP). Pembelajaran aljabar tersebut bertujuan agar siswa mampu untuk berpikir logis, analitis, sistematis, kritis, kreatif, dan kerjasama (Ramadhani W.H, 2015). 
Miskonsepsi atau salah konsep menunjuk pada salah satu konsep yang tidak sesuai dengan pengertian ilmiah yang diterima pakar di bidang itu. Menurut Brow miskonsepsi sebagai suatu gagasan yang tidak sesuai dengan pengertian ilmiah yang sekarang diterima. Sedangkan Fowler memandang miskonsepsi sebagai pengertian yang tidak akurat akan konsep, penggunaan konsep yang salah, klasifikasi contoh-contoh yang salah, kekacauan konsep-konsep yang berbeda, dan hubungan hierarki konsep-konsep yang tidak benar (Sarlina, 2015). Seorang guru semestinya memilih strategi yang tepat dalam mengajarkan konsep-konsep matematika, hal tersebut dilakukan agar konsep-konsep matematika yang diajarkan tidak keliru diterima oleh siswa sebab sangat sulit untuk mengubah pemahaman konsep yang keliru.

Suatu konsep adalah suatu kelas atau kategori stimuli yang memiliki ciri-ciri umum. Stimuli adalah objek-objek atau orang (person) (Hamalik, 2009). Miskonsepsi berbeda dari kesalahan. Kesalahan merupakan akibat dari kurangnya pemahaman tentang bentuk dan operasi aljabar. Di sisi lain, gagasan miskonsepsi merujuk pada garis pemikiran yang menyebabkan serangkaian kesalahan yang dihasilkan dari kesalahan premis yang mendasari suatu konsep atau proses tertentu (Herutomo, $\mathrm{R}$, 2017). Siswa yang memiliki konsep awal yang kurang lengkap atau tidak sempurna dapat mengalami miskonsepsi. Konsepsi awal atau prakonsep yang tidak sesuai dengan konsep ilmiah itu yang disebut dengan istilah miskonsepsi atau kesalahan konsep. Sebagaimana pendapat yang diungkapkan oleh Oliver, kesalahan adalah gejala dari struktur konseptual yang mendasari penyebab kesalahan. Hal inilah yang mendasari keyakinan dan prinsip-prinsip dalam struktur kognitif yang merupakan penyebab kesalahan konseptual sistematis yang disebut miskonsepsi (Savitri dkk, 2016).

Kesalahpahaman, di sisi lain dapat digambarkan sebagai ide-ide yang memberikan pemahaman yang salah tentang ide, objek, atau peristiwa semacam itu yang dibangun berdasarkan pengalaman seseorang termasuk hal-hal praduga, keyakinan non-ilmiah, teori naïf, konsepsi campuran atau kesalahpahaman konseptual (Thompson, 2015). Mary, Larrabee dan Charles menggunakan istilah kesalahpahaman untuk menunjuk kepada ide-ide siswa yang berbeda dari umumnya diterima oleh ilmuan. Secara garis besar, penyebab miskonsepsi diringkas dalam lima kelompok, yaitu: siswa, guru, buku teks, dan metode mengajar (Nurulwati, 2014). Beberapa cara mengetahui miskonsepsi siswa yaitu 1) Certainly of Besponse Index (CRI) merupakan teknik untuk mengukur miskonsepsi seseorang dengan mengukur tingat keyakinan atau kepastian atau kepastian seseorang dalam menjawab setiap pertanyaan yang berkaitan (Liliawati \& Ramalis, 2009). 2) Tes multiple choice dengan reasoning terbuka, pada tes ini siswa mengerjakan soal pilihan ganda serta menuliskan mengapa ia mempunyai jawaban seperti itu. Jawaban-jawaban yang salah selanjutnya dijadikan bahan tes selanjutnya. Berdasarkan jawaban yang tidak benar, peneliti mewawancarai siswa untuk meneliti mengapa siswa memilih pola pikir seperti itu (Suparno, 2013). 3) three tier test, dikembangkan oleh Eryilmaz dan Surmeli. Instrumen tes diagnostik three-tier test yang merupakan penggabungan dari two-tier test yang dikombinasikan dengan Certainty Response Index (CRI). Instrumen three-tier test memiliki kelebihan dapat membedakan antara miskonsepsi dengan kurang memahami konsep atau tidak tahu konsep melalui tingkat keyakinan dari jawaban siswa, sehingga akurat dalam mengetahui miskonsepsi (Kamilah \& Suwarna, 2016). Three-tier test adalah tes yang valid yang dapat digunakan secara efisien dengan sampel besar siswa, dan membantu para peneliti untuk memahami penalaran siswa dibalik jawaban mereka tanpa melakukan wawancara untuk membedakan miskonsepsi dari kurangnya pengetahuan (Kirbulut \& Geban, 2014). Three-tier test adalah salah satu jenis tes diagnostik yang menggunakan identifikasi miskonsepsi dan pemahaman konsep. Three-tier test memiliki tiga tingkatan, pertama adalah menanyakan pengetahuan siswa 
tentang konsep dari pilihan ganda. Tingkat kedua adalah penalaran siswa dari proses menjawab pada tingkatan pertama. Tingkatan ketiga adalah pertanyaan mengenai keyakinan siswa tentang jawaban tingkatan pertama dan kedua (Silviani \& Muliyani, 2017).

Berdasarkan hasil wawancara dengan guru kelas VII SMP Negeri 17 Makassar, siswa sering kesulitan dalam memahami konsep matematika dan menerapkannya dalam pemecahan masalah. Permasalahan tersebut bisa saja terjadi karena siswa lebih suka menghafal rumus sehingga terjadi pengertian yang tidak akurat tentang konsep, penggunaan konsep yang salah, dan pemaknaan konsep yang berbeda. Hal tersebut menyebabkan siswa mengalami miskonsepsi, contohnya ketika siswa mengerjakan soal penjumlahan aljabar, siswa sering kali menjumlahkan variabel yang berbeda. Berdasarkan hasil observasi diperoleh bahwa siswa kurang aktif dalam proses pembelajaran dan metode yang digunakan guru adalah metode ceramah.

Atas dasar pemikiran tersebut, untuk mengetahui miskonsepsi yang dilakukan oleh siswa dalam menyelesaikan soal-soal pada pokok bahasa aljabar, maka peneliti akan mengkaji secara ilmiah tentang miskonsepsi materi aljabar pada siswa kelas VII SMP Negeri 17 Makassar.

\section{Metode Penelitian}

Metode yang digunakan dalam penelitian ini adalah metode penelitian kualitatif. Metode penelitian kualitatif merupakan metode penelitian yang berlandaskan pada filsafat postpositivisme, digunakan untuk meneliti pada kondisi obyek yang alami, dimana peneliti adalah instrumen kunci, pengambilan sampel sumber data dilakukan secara purposive atau snowball, teknik pengumpulan data dengan triangulasi (gabungan), analisis data bersifat induktif/kualitatif, dan hasil penelitian kualitatif lebih menekankan makna daripada generalisasi.

Penelitian ini dilakukan di SMP Negeri 17 Makassar, yang beralamat di jalan Tamangapa Raya Kecamatan Manggala Kota Makassar. Penelitian ini merupakan penelitian kualitatif sehingga subjek penelitian yang digunakan untuk mendapatkan data tidak dipilih secara acak tetapi dilakukan secara selektif sesuai dengan tujuan yang ingin dicapai dalam penelitian, yaitu untuk mengetahui miskonsepsi siswa kelas VII 2 SMP Negeri 17 Makassar. Pemilihan subjek tersebut dilakukan dengan memberikan kriteria yang didasarkan pada hasil three-tier test.

Penelitian ini menggunakan triangulasi sumber data dengan menguji keabsahan data melalui 4 langkah yaitu keterpercayaan (credibility), keteralihan (transferability), kebergantungan (dependability), dan kepastian (comfirmability). teknik analisis data menggunakan reduksi data, display data dan kesimpulan dan verifikasi.

\section{Hasil dan Pembahasan}

\subsection{Menjelaskan Konsep Aljabar}

Indikator ini terdiri dari 1 butir soal yaitu butir soal nomor 1. Pada butir soal nomor 1 semua siswa menjawab salah dan siswa yang teridentifikasi mengalami miskonsepsi (false negative) sebesar $80 \%$. Pemahaman siswa yang teridentifikasi mengalami miskonsepsi (false negative) Pada butir soal nomor 1 ditunjukkan dari jawaban siswa yang memilih S-B-Y. Jawaban tersebut menjelaskan bahwa siswa menganggap bahwa suatu bentuk matematika yang dalam penyajiannya memuat huruf-huruf untuk mewakili bilangan yang belum diketahui merupakan definisi dari variabel. Oleh karena itu dapat disimpulkan bahwa siswa mengalami miskonsepsi terkait konsep aljabar. Siswa mengalami 
miskonsepsi (false negative) dikarenakan belum memahami secara utuh terkait pengertian dari aljabar.

\subsection{Mengidentifikasi Unsur-Unsur Aljabar}

Indikator ini terdiri dari 2 butir soal yaitu butir soal nomor 2 ,butir soal nomor 3 dan butir soal nomor 9 tentang menentukan suku, variabel, koefisien dan konstanta. Pada soal tes nomor 2, hanya 5 siswa yang menjawab dengan benar dan 25 siswa yang menjawab salah. Siswa yang teridentifikasi mengalami miskonsepsi sebesar 30\% dan miskonsepsi (false positive) sebesar 7\%. Pemahaman siswa yang mengalami miskonsepsi pada nomor 2 ditunjukkan dari jawaban siswa yang memilih S-S-Y. Siswa yang teridentifikasi mengalami miskonsepsi (false positive) pada nomor 2 ditunjukkan dari jawaban siswa yang memilih B-S-Y. Jawaban tersebut menunjukkan kurangnya pemahaman siswa mengenai definisi variabel ,koefisien, dan konstanta.

Pada butir soal nomor 3, siswa yang menjawab salah sebanyak 24 siswa dan hanya 6 siswa menjawab benar. Pada butir soal ini siswa yang teridentifikasi mengalami miskonsepsi sebesar 33\%. Pemahaman siswa yang teridentifikasi miskonsepsi ini ditunjukkan dari jawaban siswa yang memilih jawaban S-S-Y. Jawaban tersebut menunjukkan siswa kesulitan dalam menentukan koefisien dan konstanta, sehingga dapat dikatakan siswa keliru dalam membedakan antara variabel, konstanta dan koefisien.

Pada soal butir nomor 9, siswa yang menjawab dengan jawaban salah sebanyak 24 siswa dan hanya 6 siswa menjawab benar. Pada butir soal ini siswa yang teridentifikasi mengalami miskonsepsi sebesar $27 \%$ dan miskonsepsi (false positive) sebesar 3\%. Pemahaman siswa teridentifikasi miskonsepsi ini ditunjukkan dari jawaban siswa yang memilih jawaban S-S-Y. Pemahaman siswa teridentifikasi miskonsepsi (false positive) ini ditunjukkan dari jawaban siswa yang memilih jawaban B-S-Y. Jawaban tersebut menunjukkan siswa kesulitan dalam menentukan suku dalam aljabar.

Reny Silviani mengemukakan bahwa miskonsepsi banyak berasal dari dalam diri siswa. Miskonsepsi yang berasal dari dalam siswa dapat dikumpulkan dalam beberapa hal, yaitu minat siswa dan kemampuan siswa (Silviani \& Muliyani, 2017). Hal ini sejalan dengan miskonsepsi yang dialami siswa dalam indikator mengidentifikasi unsur-unsur aljabar yang disebabkan oleh kurangnya minat belajar siswa dan rendahnya tingkat pemahaman siswa.

\subsection{Menyelesaikan Operasi Penjumlahan dan Pengurangan}

Indikator ini terdiri dari 6 butir soal yaitu butir soal nomor $6,7,8,12$ tentang menentukan bentuk sederhana dari aljabar dan soal butir nomor 11 dan 13 tentang menentukan hasil jumlah dari bilangan aljabar.

Pada butir soal nomor 6, siswa yang menjawab dengan jawaban salah sebanyak 30 siswa. Siswa yang teridentifikasi miskonsepsi sebesar 63\% dan miskonsepsi (false positive) sebesar 3\%. Pemahaman siswa teridentifikasi miskonsepsi ini ditunjukkan dari jawaban siswa yang memilih jawaban S-S-Y. Pemahaman siswa teridentifikasi miskonsepsi (false positive) ini ditunjukkan dari jawaban siswa yang memilih jawaban B-S-Y. Jawaban tersebut menjelaskan bahwa siswa kesulitan untuk menyatukan variabel yang sama atau sejenis disebabkan karena kurangnya pemahaman siswa dalam konsep aljabar.

Pada butir soal nomor 7, siswa yang menjawab dengan jawaban salah sebanyak 17 siswa dan 13 siswa menjawab dengan jawaban benar. Siswa yang teridentifikasi miskonsepsi sebesar 27\%, Miskonsepsi (false positive) sebesar 17\%. Pemahaman siswa teridentifikasi miskonsepsi ini ditunjukkan dari jawaban siswa yang memilih jawaban S-S-Y. Pemahaman siswa teridentifikasi miskonsepsi (false positive) ini ditunjukkan dari jawaban siswa yang memilih jawaban B-S-Y. Kedua 
jawaban tersebut menunjukkan bawah pada butir soal nomor 7 siswa juga kesulitan dalam menyatukan variabel yang sama atau sejenis.

Pada butir soal nomor 8, siswa yang menjawab dengan jawaban salah sebanyak 25 siswa dan hanya 5 siswa menjawab dengan jawaban benar. Siswa yang teridentifikasi miskonsepsi sebesar 37\%, Pemahaman siswa teridentifikasi miskonsepsi ini ditunjukkan dari jawaban siswa yang memilih jawaban S-S-Y. Jawaban tersebut menunjukkan bahwa pada butir soal nomor 8 siswa juga kesulitan dalam menyatukan variabel yang sama atau sejenis, sehingga dapat dikatakan siswa salah menginterpretasikan cara penyelesaian operasi penjumlahan dan pengurangan bilangan aljabar.

Pada butir soal nomor 11 siswa yang menjawab dengan jawaban salah sebanyak 27 siswa dan hanya 3 siswa menjawab dengan jawaban benar. Siswa yang teridentifikasi miskonsepsi sebesar 7\%, Pemahaman siswa teridentifikasi miskonsepsi ini ditunjukkan dari jawaban siswa yang memilih jawaban S-S-Y. Jawaban tersebut menjelaskan bahwa kurangnya pemahaman siswa dalam melakukan substitusi.

Pada butir soal nomor 12, siswa yang menjawab dengan jawaban salah sebanyak 30 siswa. Siswa yang teridentifikasi miskonsepsi sebesar 30\%. Pemahaman siswa teridentifikasi miskonsepsi ini ditunjukkan dari jawaban siswa yang memilih jawaban S-S-Y, maka dapat disimpulkan bahwa kurangnya pemahaman terkait operasi aljabar menyebabkan siswa tidak mampu menjawab soal dengan operasi penjumlahan dan pengurangan.

Pada butir soal nomor 13, siswa yang menjawab dengan jawaban salah sebanyak 30 siswa. Tidak satupun siswa yang teridentifikasi mengalami miskonsepsi berdasarkan hasil dari pengujian three tier-test.

Dari hasil data di atas, miskonsepsi terjadi pada indikator menyelesaikan penjumlahan dan pengurangan. Persentase miskonsepsi menunjukkan bahwa kurangnya pemahaman siswa terkait menyatukan variabel dan melakukan subtitusi atau penggantian. Sejalan dengan pendapat Ozkan dalam Karolin bahwa pemahaman yang rendah terhadap suatu konsep menjadikan siswa membuat pengertian sendiri terhadap konsep tersebut (Natalia dkk, 2016). Hal ini menunjukkan bahwa siswa mengalami miskonsepsi dikarenakan kemampuan siswa dalam memahami konsep aljabar kurang mumpuni.

\subsection{Menyelesaikan Operasi Perkalian dan Pembagian}

Indikator ini terdiri dari 4 butir soal yaitu butir soal nomor 4, 5, 10,dan 15. Pada butir soal nomor 4, siswa dihadapkan dengan soal aljabar dalam kehidupan sehari-hari. Pada butir soal nomor 5 dan 10, siswa diminta untuk menentukan hasil kasil dari bilangan aljabar. Pada butir soal nomor nomor 15 siswa diminta untuk menentukan hasil bagus dari 2 bilangan aljabar.

Pada butir soal nomor 4, siswa yang menjawab dengan jawaban salah sebanyak 10 siswa dan hanya 20 siswa menjawab benar. Pada butir soal ini siswa yang teridentifikasi mengalami miskonsepsi 10\%, miskonsepsi (false positive) 27\%. Pemahaman siswa teridentifikasi miskonsepsi ini ditunjukkan dari jawaban siswa yang memilih jawaban S-S-Y, sedangkan siswa yang teridentifikasi mengalami miskonsepsi (false positive) ditunjukkan dari jawaban siswa yang memilih B-S-Y. Jawaban tersebut menunjukkan kesalahan siswa dalam mengubah soal cerita ke bentuk aljabar.

Pada butir soal nomor 5, siswa yang menjawab dengan jawaban salah sebanyak 21 siswa dan hanya 9 siswa menjawab dengan jawaban benar. Pada butir soal ini siswa yang teridentifikasi mengalami miskonsepsi 13\%. Pemahaman siswa teridentifikasi miskonsepsi ini ditunjukkan dari jawaban siswa yang memilih jawaban S-S-Y. Jawaban tersebut bahwa siswa salah dalam menentukan hasil kali variabelnya. 
Pada butir soal nomor 10, siswa yang menjawab dengan jawaban salah sebanyak 24 siswa dan hanya 6 siswa menjawab dengan jawaban benar. Pada butir soal ini siswa yang teridentifikasi mengalami miskonsepsi 17\%, miskonsepsi (false positive) 27\%, dan miskonsepsi (false negative) 3\%. Pemahaman siswa teridentifikasi miskonsepsi ini ditunjukkan dari jawaban siswa yang memilih jawaban S-S-Y. Pemahaman siswa teridentifikasi miskonsepsi (false positive) ini ditunjukkan dari jawaban siswa yang memilih jawaban B-S-Y. Pemahaman siswa teridentifikasi miskonsepsi (false negative) ini ditunjukkan dari jawaban siswa yang memilih jawaban S-B-Y. Ketiga jawaban tersebut menunjukkan bahwa siswa salah dalam menentukan hasil kali bilangan aljabar.

Pada butir soal nomor 15, siswa yang menjawab salah sebanyak 22 siswa dan hanya 8 siswa menjawab dengan benar. Pada butir soal ini siswa yang teridentifikasi mengalami miskonsepsi $17 \%$. Pemahaman siswa teridentifikasi miskonsepsi ini ditunjukkan dari jawaban siswa yang memilih jawaban S-S-Y. Jawaban tersebut menunjukkan bahwa siswa melakukan kesalahan dalam operasi pembagian antara variabel.

Dari data tersebut, miskonsepsi terjadi pada indikator menyelesaikan perkalian dan pembagian. Persentase miskonsepsi menunjukkan bahwa kurangnya pemahaman siswa terkait menyatukan variabel dan melakukan substitusi atau penggantian. Hal ini sejalan dengan pendapat Ozkan dalam Karolin bahwa pemahaman yang rendah terhadap suatu konsep menjadikan siswa membuat pengertian sendiri terhadap konsep tersebut (Natalia dkk, 2016). Sesuai yang dikatakan Sarlina bahwa miskonsepsi menunjuk pada salah satu konsep yang tidak sesuai dengan pengertian ilmiah yang diterima pakar di bidang itu (Sarlina, 2015).

Berdasarkan hasil three tier-test yang telah dilakukan, menunjukkan terjadinya miskonsepsi pada semua indikator materi aljabar. Hal tersebut sejalan dengan hasil wawancara yang dilakukan terhadap siswa dan guru teridentifikasi penyebab terjadinya miskonsepsi dari siswa yaitu kurang memahami konsep aljabar, kurangnya minat belajar aljabar, rasa tidak nyaman ketika belajar aljabar karena ruang kelas yang sempit, dan prakonsep praaljabar, sedangkan dari guru yaitu metode ceramah kurang cocok digunakan dalam proses pembelajaran materi aljabar, dimana pada pelajaran matematika khusus materi aljabar diperlukan metode mengajar yang bisa membuat siswa tertarik sehingga akan meningkatkan minat belajar siswa. Guru juga kurang memahami apa itu miskonsepsi dan penyebab miskonsepsi sehingga guru akan kesulitan menanggulangi miskonsepsi. Kedua hal ini akan menyebabkan siswa mengalami miskonsepsi.

\section{Kesimpulan}

Berdasarkan hasil penelitian dan pembahasan maka dapat disimpulkan bahwa berdasarkan hasil three tier-test yang diberikan kepada siswa kelas VII 2 teridentifikasi siswa mengalami miskonsepsi pada materi aljabar dengan persentase 33\% dari 30 siswa. Miskonsepsi mayoritas terjadi pada semua materi aljabar yaitu: konsep aljabar, unsur-unsur aljabar, operasi penjumlahan, operasi pengurangan, operasi perkalian dan operasi pembagian. Adapun faktor-faktor penyebab miskonsepsi siswa kelas VII 2 SMP Negeri 17 Makassar yaitu 1) kurangnya kemampuan siswa dalam memahami konsep aljabar secara mendalam, 2) kurangnya minat belajar siswa khusus aljabar, 3) metode yang sering digunakan oleh guru yaitu metode ceramah, sehingga membuat siswa kesulitan memahami materi aljabar, 4) prakonsep praaljabar. 


\section{Daftar Pustaka}

Hamalik, O. (2009). Perencanaan Pengajaran berdasarkan Pendekatan Sistem. Jakarta: PT Bumi Aksara.

Hasbullah. (2013). Dasar-Dasar Ilmu Pendidikan. Jakarta: Rajawali Press.

Herutomo, R. (2017). Miskonsepsi Aljabar: Konteks Pembelajaran. J. Basication J. Pendidik. Dasar, Vol. 1, No. November, pp. 1-8.

Kamilah, D.S \& Suwarna, I.P. (2016) Pengembangan Three0Tier Test Digital untuk Mengidentifikasi Miskonsepsi pada Konsep Fluida Statis, Edusains, Vol. 8, No. 2, pp. 212-220.

Kirbulut, Z.D \& Geban O. (2014). Using Three-Tier Diagnostic Test to Assess Students' Misconceptions of States of Matter, Eurasia J. Math. Sci. Technol. Educ, Vol. 10, No. 5, pp 509-521.

Liliawati, W. \& Ramalis, T.R. (2009). Identifikasi Miskonsepsi Materi IPBA di SMA dengan menggunakan CRI (Certainty of Respons Index) dalam Upaya Perbaikan Urutan Pemberian Materi IPBA pada KTSP, Pros. Semin. Nas. Penelitian, Pendidikan, dan Penerapan MIPA, pp. 159-168.

Natalia, K dkk. (2016). Miskonsepsi pada Penyelesaian Soal Aljabar Siswa Keas VIII berdasarkan Proses Berpikir Mason, J. Pendidik - Teor, Penelitian, dan Pengemb., Vol. 1, No. 10, pp 1917-1925.

Nurulwati. (2014). Suatu Tinjauan tentang Jenis-Jenis. Vol. 02, No. 01, pp. 87-95.

Ramadhani, W.H, Hartoyo, A, \& Mirza, A. (2015). Miskonsepsi Siswa pada Materi Operasi pada Bentuk Aljabar Kelas VII SMP Haebat Islam. Jurnal Pendidikan dan Pembelajaran Khatulistiwa. Vol. 4. No. 1.

Sarlina. (2015). Miskonsepsi Siswa terhadap Pemahaman Konsep Matematika pada Pokok Bahasan Persamaan Kuadrat Siswa Kelas X5 SMA Negeri 11 Makassar. Mapan J. mat. Dan Pembelajaran, Vol 3, No 2, pp. 194-209.

Savitri, M.E., Mardiyana, \& Subanti, S. (2016). Analisis Miskonsepsi Siswa pada Materi Pecahan dalam Bentuk Aljabar ditinjau dari Gaya Kognitif Siswa Kelas VIII di SMP Negeri 2 Adimulyo Kabupaten Kebumen Tahun Ajaran 2013/2014, Jurnal Elektronik Pembelajaran Matematika, Vol. 4, No. 4. pp. 401-413.

Silviani, Y.K.R \& Mulyani, R. (2017) Penerapan Three Tier-Test untuk Identifikasi Kuantitas Siswa yang Miskonsepsi pada materi Magnet, Vol. 2, No. 1, pp. 10-11.

Stein, M., T.g Larrabee, \& C.R. Barman. (2013). A Study of Common Beliefs and Misconceptions in Physical Science, J. Elem Sci. Educ, Vol. 20, No. 2, pp. 1-11.

Suparno, P. (2013). Miskonsepsi dan Perubahan Konsep dalam Pendidikan Fisika. Jakarta: PT. Grasindo.

Thompson, F. (2015). An Exploration of Common Student Misconceptions in Science Fiona, Procedia-Soc. Behav. Sci., Vol. 143, No. 4, pp. 693-697. 